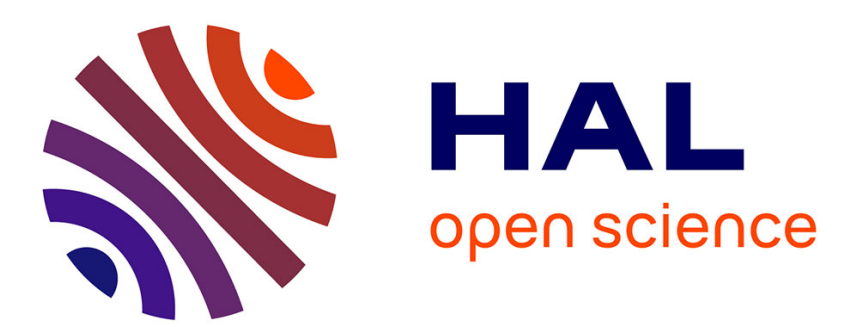

\title{
Product price differences across countries: determinants and effects
}

Robert E. Lipsey, Birgitta Swedenborg

\section{To cite this version:}

Robert E. Lipsey, Birgitta Swedenborg. Product price differences across countries: determinants and effects. Review of World Economics, 2010, 146 (3), pp.415-435. 10.1007/s10290-010-0064-8 . hal00606276

\section{HAL Id: hal-00606276 \\ https://hal.science/hal-00606276}

Submitted on 6 Jul 2011

HAL is a multi-disciplinary open access archive for the deposit and dissemination of scientific research documents, whether they are published or not. The documents may come from teaching and research institutions in France or abroad, or from public or private research centers.
L'archive ouverte pluridisciplinaire HAL, est destinée au dépôt et à la diffusion de documents scientifiques de niveau recherche, publiés ou non, émanant des établissements d'enseignement et de recherche français ou étrangers, des laboratoires publics ou privés. 


\title{
Revised August 19, 2009 (Revised June 3, 2010)
}

\section{PRODUCT PRICE DIFFERENCES ACROSS COUNTRIES \\ - DETERMINANTS AND EFFECTS}

\author{
Robert E. Lipsey
}

Birgitta Swedenborg

Robert E. Lipsey

National Bureau of Economic Research 365 Fifth Avenue, $5^{\text {th }}$ Floor

New York, New York 10016-4309

rlipsey@gc.cuny.edu

Fax: (212) 817-1597

Tel: (212) 817-7961

\section{Corresponding Author:}

Birgitta Swedenborg

Studieförbundet Näringsliv och Samhälle Center for Business and Policy Studies

Box 5629

S-114 86 Stockholm, Sweden birgitta.swedenborg@ @ns.se Tel: 46-8-50 702568 


\begin{abstract}
A substantial part of international differences in prices of individual products, both goods and services, can be explained by differences in per capita income, wage compression, or low wage dispersion among low-wage workers, and exchange rate fluctuations. Higher per capita income is associated with higher prices and higher wage dispersion with lower prices. The effects of higher income and wage dispersion are moderated for the more tradable products. The effects of wage dispersion, on the other hand, are magnified for the more labor-intensive products, particularly low-skill services. The differences in prices across countries are reflected in differences in the composition of consumption. Countries in which prices of labor-intensive services are very high, such as the Nordic countries, consume much less of them. For some services, the shares of GDP consumed in high-price countries are less than 20 percent of the shares in low-price countries. Since these are services of very low tradability, the low consumption levels of these services imply low employment in them.
\end{abstract}

Keywords: International price comparisons, tradability, labor intensity, wage dispersion, consumption

JEL Codes: E31, F31. F16, J23, J31, J33 


\section{Product Price Differences Across Countries - Determinants and Effects \\ Robert E. Lipsey and Birgitta Swedenborg}

\section{Introduction}

International differences in national price levels and prices of individual products are striking and have persisted over long periods, despite the presumed equalizing influence of international trade and despite the liberalization of trade and reduction of transport costs that have occurred. For example, prices in Japan in the 1980s and 1990s were 40 percent higher, on average, than for the OECD countries as a group. In the Nordic countries and Switzerland, prices were 15 to 25 percent higher. In the United States, by contrast, prices were 10 percent lower, and in Portugal 20 percent lower than the OECD average.

Individual product prices often differ even more sharply from one country to another. In 1999, for example, prices for Office Machines and Equipment in Austria were twice as high as in the United States, and they were almost twice as high in France. Prices for Domestic and Other Household Services in Norway were 3 to 4 times as high as in the United States and 3 times as high as in Ireland.

Most explanations of the causes of national price differences focus on factors that affect the prices of less tradable products, especially services, since price differences tend to be eroded in the more tradable sectors of the economy. However, most empirical studies have analyzed differences in national price levels rather than in prices of individual products. In an earlier paper (Lipsey and Swedenborg, 1999), the present authors examined the determinants of product prices across countries, distinguishing between goods prices and service prices. We found that country characteristics such as per capita income and wage compression, specifically relatively 
high wages of the least skilled, raised the price of services somewhat more than the price of goods. But the difference was rather small. We concluded that the dichotomy between goods and services was an oversimplification, partly because all goods prices had a nontradable component in the form of domestic transportation and distribution costs. We also suggested, but did not test, that the effect of per capita income and wage compression would vary depending on the labor intensity of the final product.

In this paper, we examine how international differences in goods and service prices are explained by not only country characteristics, but particularly by the interaction between country characteristics and the characteristics of the individual goods and services. We focus on the role of a product's tradability and labor intensity in offsetting or intensifying the effect of country characteristics such as per capita income and wage compression. Then, we elaborate on the implications of our findings for particular types of countries and products. We go on to show how differences in relative prices impact the composition of consumption in different countries and, in particular, offer an explanation as to why unskilled-labor-intensive activities are less important in some countries than in others.

The analysis covers about 200 products across 20 OECD countries from 1985 to 1999. Country characteristics include real per capita income, wage compression, and medium-term fluctuations in exchange rates. The product characteristics are a product's tradability and labor intensity. A novel feature of our calculation of labor intensity is that we add an estimate of the labor content of distribution to that in production.

One of the rare analyses of determinants of product price differences across countries is that of Crucini et al. (2005), who analyze the determinants of the deviations from the Law-ofOne-Price (LOP). Their analysis is based on Eurostat's collection of detailed product level data 
(reaching 1,100 products in 1990) for European Union countries (from 9 in 1975 to 13 in 1990), as part of the International Comparison Program.. Their approach differs from ours but their results are broadly consistent with ours. We will comment more on this in Section 3 below.

The evidence we present indicates that high per capita income and high wage compression, or low wage dispersion, are associated with high prices of labor-intensive and less tradable products, reducing both consumption and production of these products and consequently also employment in these industries in a country. The effect of wage compression highlights a rather neglected effect of what is sometimes called a "solidaristic" or egalitarian, wage policy, namely, that at least part of the cost of the policy is borne by consumers. While the effect of high statutory and negotiated minimum wages and the associated labor market institutions on unemployment (e.g., Bertola et al. 2001) and the structure of employment (e.g., Freeman and Schettkat 2001; Davis and Henrekson 2004) have been the subject of some analysis, their effect on prices has not received similar attention.

The paper proceeds as follows. Section 2 describes briefly the explanations that have been offered for international price differences and motivates the variables used in the empirical analysis. Section 3 presents the regression results. Section 4 discusses the quantitative importance of the findings on particular types of products, and Section 5 shows how relative prices affect the composition of consumption. Section 6 concludes.

\section{Explanations for International Price Differences}

The traditional explanation of international differences in aggregate national price levels attributed them to differences in real per capita income. The gross relationship between income and unweighted averages of individual price levels for OECD countries since 1985 is shown in 
Figure 1 in Appendix 1. The relationship is positive, as expected, with Japan accounting for some extremely large positive outliers and the United States for large negative outliers.

The traditional explanation for this positive relationship was based on the dichotomy between services, assumed to be nontradable, and goods, assumed to be tradable and therefore subject to the international equalization of prices through trade. International price level differences were assumed to be concentrated in the nontradable service sector, with high per capita income associated with high service prices. A basic assumption was that exchange rates and prices of labor were determined in the tradable, or goods sector, where high-income countries enjoyed large productivity advantages over low-income countries. The second basic assumption was that in the service sector, productivity differences between rich and poor countries were smaller than in the goods sector. The combination of large wage differences determined by goods sector productivity, with small differences in service sector productivity, caused services to be expensive in rich countries. That explanation in terms of difference in productivity relationships is often referred to as the Balassa-Samuelson effect, although it has a long history, going back to Ricardo (1817). Some of the history of this explanation is described in Kravis and Lipsey (1983).

A different explanation of the role of service industries in price level differences was given by Kravis and Lipsey (1983) and Bhagwati (1984). Without any assumptions about productivity differentials between goods and services, they ascribed the higher prices of services in rich countries to the higher labor intensity of services than of goods, combined with the higher prices of labor in the rich countries. This explanation seems to us more plausible but has the added advantage that it is easier to test, since industry labor intensities are easier to measure than the multifactor productivity levels relevant to the first explanation. 
The continuing series of international price and income comparisons stemming from the International Comparison Program has made it clear that the goods-services dichotomy is an oversimplification. "The price level for tradables...rises as income rises, despite the near unanimity found in the literature on real exchange rates that the law of one price prevails for tradables" (Kravis and Lipsey, 1988, p. 475).

Two earlier studies by the present authors examined food price differences across countries and price differences in general at a fairly disaggregated level. Agricultural protection played an important role in explaining large differences in food prices (Lipsey and Swedenborg 1996). More generally, high per capita income, temporarily high currency exchange values, high levels of protection, and wage compression, or low wage dispersion in a country's labor market, were associated with high product prices (Lipsey and Swedenborg 1999).

In this paper, we examine how country characteristics interact with product characteristics to determine the prices for individual goods and services. We focus on the characteristics of individual products (including services), such as their tradability and labor intensity, that might affect their response to the country characteristics, such as per capita income, wage dispersion, and exchange rate fluctuations.

Products differ widely in their tradability, which we measure by rough estimates of worldwide ratios of trade to consumption. The ratios range from close to zero in some services to a median level of over 60 per cent in clothing and footwear, as can be seen in Table 6 in Appendix 1. Higher tradability for a product should weaken the effect of per capita income and wage compression by moving price levels toward international averages.

The labor intensity of a product at the consumer level incorporates not only the inputs of labor and capital in its production, but also the transportation, and wholesale and retail trade 
margins for it, and the factor intensities in these service sectors. These distribution margins differ widely across product groups, from under 17 per cent on average in machinery and equipment, to more than three quarters in clothing and footwear, as is shown in Table 7 in Appendix 1. We take account of distribution costs by adding the factor intensities in the transportation, wholesale, and retail trade industries to those in the producing industries themselves to arrive at the factor intensities of the final products. We expect labor intensity to strengthen the effect of per capita income and wage compression.

A product variable tried, but discarded, was a crude measure of the skill intensity of a product, the average wage per worker. The variable was strongly correlated with labor intensity. An extreme version of our incorporation of trade margins and transport costs in calculating factor intensity would be to assume that all traded products are "middle products" in the sense of Sanyal and Jones (1982), with prices at the borders equalized by competition. In that case, the labor intensity of production of the product itself would be irrelevant, and only the labor intensity in the nontraded transport, wholesaling, and retailing would affect the final product price. That assumption would imply that the employment and value added in the industry producing the product are irrelevant and should be dropped from the factor intensity formula, leaving only the factor content in the supposedly nontraded services.

Wage compression, defined as a low level of wage dispersion in the lower parts of the wage distribution, is measured here as the ratio of the median wage to the wage at the $10^{\text {th }}$ percentile. While not directly a policy variable, wage compression is presumed to be at least partially a reflection of "interventionist labor market institutions" (Bertola et al. 2001, p. 6). More broadly, wage compression has been associated with minimum wage regulations, employment protection, unemployment benefit generosity and duration, and union strength 
(Freeman et al. 1997; Koeniger et al. 2004). All of these interventions are stronger, and wage compression is greater, in Europe than in the United States.

The gross relationship between wage dispersion and the unweighted averages of price levels in the OECD countries since 1985 is negative, as shown in Figure 2 in Appendix 1.

The effect of wage dispersion on price should be larger, the more labor-intensive, and especially the more unskilled-labor-intensive, a product is. A country in which labor markets are relatively unregulated by law, centralized bargaining, or union power will produce products intensive in unskilled labor cheaply, using low-wage labor. A country in which government or union regulations make even the lowest-skill labor expensive will have high prices for products intensive in unskilled labor, especially the less tradable ones, and, as a result, higher overall price levels. The effect of wage compression should be smaller, the more cheaply or conveniently the product can be traded.

Another possible determinant of product prices is product market regulation. A measure of product market regulation constructed at the OECD (Conway et al. 2005) was tried in some equations, but did not contribute to the explanation of prices. A reason for the failure to find effects of product regulation was given by a comparison in Blanchard and Giavazzi (2003) between levels of product regulation and levels of employment protection legislation, showing that the two were strongly correlated. Thus any effects of product market regulation may be incorporated in those we find for wage dispersion.

Indirect tax levied on products sold in the country, but not on exports from the country is, a further reason for price differences between countries. Different measures of indirect taxes were tried but discarded as they did little to improve the fit of the equations. 
Per capita income and wage compression are not the only country characteristics to influence country price levels. Exchange rate changes can also do so, at least over short periods over which prices do not fully respond to exchange rate movements. We have used as our exchange rate variable here, deviations from nine-year averages of exchange rates. Other variants were tried, including deviations from shorter and longer trends, and exchange rate coefficients differed, but the coefficients of other variables were not much affected by the choice of exchange rate measures.

We have not been able to take account of country differences in trade barriers on the individual product level, a potentially important reason for price differences. Available measures were either extremely detailed and too difficult to match to our data set, e.g., those given by the World Bank's TRAINS data set, or did not cover all countries and years. However, market support estimates for agricultural products, a form of protection found to be significant influences on food prices in Lipsey and Swedenborg (1996), are included in calculating predicted prices for the related food products but the coefficients are not shown here because they were not relevant for explaining prices in general.

\section{Regression results}

Equations for some 200 individual product prices have been run for 1985, 1990, 1993, 1996, and 1999 data, pooled, with various combinations of year dummies and country dummies. For comparison, we have also run equations for aggregate country price levels in the same years.

The form of the equations, with some variations, is as follows: 
(1) $P R(i, j, y)=f[R G D P C(j, y), W D(j, y), X R(j, y), R G D P C(j, y) \times \operatorname{TR}(i), R G D P C(j, y) \mathrm{x}$ $L I(i), W D(j, y)$ х $T R D(i), W D(j, y)$ х $L I(i), D(j), D(y)]$.

Where:

$P R(i, j, y)=$ Price of product $i$ in country $j$ in year $y$, relative to the average price of that product in all countries in that year.

$R G D P C(j, y)=$ Real GDP per capita in country $j$ in year $y$ relative to the average in all countries.

$W D(j, y)=$ Wage dispersion in country $j$ relative to average in all countries in year $y$. $X R(j, y)=$ Exchange rate deviation of country $j$ in year $y$. $T R D(i)=$ Tradability of product $j$, measured as the worldwide ratio of trade to output, relative to the average tradability of all products.

$L I(i, y)=$ Labor intensity of product $i$ relative to the average labor intensity of all products in year $y$.

$D(j)=$ Dummy variable for country $j$

$D(y)=$ Dummy variable for year $y$.

Definitions and measures of variables are described in detail in Appendix 2. Dummy variables for products were tried, but, because each product price was measured relative to the mean for all countries, they were never significant and were dropped. 


\subsection{Aggregate price levels}

Equation 1, pooled for all the years for which we have the individual product prices, shows how country characteristics influence the aggregate price level in different countries. The product in this case is the aggregate country real GDP, calculated with international weights.

$$
\begin{aligned}
& P R(j, y)=0.6661^{* * *} R G D P C(j, y)-0.4694^{* * *} W D(j, y)+1.1173 * * * X R(j, y)+0.8023^{* * *} \\
& \text { (0.0776) } \\
& \text { (0.0848) } \\
& (0.2299)
\end{aligned}
$$

Figures in parentheses are standard errors.

Over half of the variance among aggregate national price levels is explained by per capita income, wage dispersion, and short-term fluctuations in the exchange rate. Higher per capita income and lower wage dispersion produce higher national price levels. Deviations of a country's exchange rate from a nine-year moving average produced corresponding, but somewhat larger, deviations in the country's GDP price level.

It might be expected that membership in the European Union, with its large free trade area, would affect country price levels. By intensifying competition in member countries the single market might make prices lower than they otherwise would have been. However, this expectation is not borne out in Equation 2. There, we distinguish, in each year, between members of the European Union in that year and nonmembers but find that membership had no significant effect on the aggregate price level, or on the coefficients. One reason for this might be that some new EU members, as well as some nonmembers, had previously had the benefits of a free-trade area without actually being members of the EU. That still applies to Norway and Switzerland, for example (under the so-called European Economic Space Agreement). 
(3)

$$
\begin{gathered}
\left.P R(j, y)=\begin{array}{c}
0.6227^{* * *} \\
(0.0776)
\end{array}\right)\left(0.085 P C(j, y)-0.4871^{* * *} W D(j, y)+1.1588^{* * * *} X R(j, y)\right. \\
-0.0370 E U(j, y)+0.8836 * * *
\end{gathered}
$$

$$
\text { ADJ RSQ }=0.5819 \quad \text { NOBS }=99
$$

$* * *=$ significant at the $1 \%$ level

Figures in parentheses are standard errors

Adding country size, as measured by real GDP, to the equation, on the theory that larger countries, too, might be characterized by more intense competition or enjoy economies of scale in the nontradable sector, added nothing to the explanation of prices.

\subsection{Individual product prices}

The equation for individual product prices, pooling all products, countries, and years, is shown in Table 1. We make no distinction between goods and services, on the ground that the ranges of the product characteristics encompass the relevant distinctions. The equation includes one country dummy, for Japan.

The explanatory power of the individual product price equation, in comparison to that of the aggregate price equation, is limited by the pooling, in the sense that idiosyncratic features of price setting for individual products in individual countries cannot be taken into account. The one exception is protection levels for some individual food products that are positive and significant for the price of vegetable oils, grains, meats, and milk. However, there must be many other taxes, regulations, and institutions that vary across product-country combinations, but which we have not taken into account.

The positive influence of per capita income levels on prices is evident, but the coefficient is considerably smaller than in the aggregate equation, partly because it is significantly modified 
by international trade and product characteristics. The more tradable a product is, the smaller the effect of per capita income on its price. The higher the labor intensity in production and distribution of a product is, the greater the effect of per capita income in the consuming country on product price. Both these interaction effects suggest that the influence of per capita income on country price levels is to a large degree due to the fact that there is a nontradable component in final consumption and, furthermore, that the nontradable component is often relatively labor intensive.

Wage dispersion, at the mean level, of product tradability and labor intensity, has a significant negative effect on product prices, much larger than that shown by the aggregate equation. The effect is reduced by greater tradability of a product, but strengthened by higher labor intensity.

Temporarily high values of a country's currency are associated with high prices, indicating that domestic prices do not change so as to offset exchange rate deviations from longterm trends.

In general we are reluctant to use country dummies. We make the exception for Japan because this country is such an extreme outlier, with very high prices. A Japan dummy captures what we are unable to explain about Japan with these or other variables. It has little effect on the overall explanatory value of the estimates, or on the coefficients of other variables.

\section{TABLE 1 ABOUT HERE}

We do not use country fixed effects more generally because our interest is in crosscountry variation, rather than in the changes over time that would be revealed by introducing country fixed effects. Since many of our country characteristics do not show much variation over 
time, an ambiguity in our analysis is that we cannot be sure which relatively slow moving characteristic of a country is determining our results. For example, various aspects of labor market policy might be concealed in the variable we refer to as wage dispersion. We try to reduce that ambiguity by adding the interactions of the country variables with product characteristics, introducing a source of variation not provided by the country characteristics themselves. We interpret the fact that the interaction variables have the expected sign and are significant as providing support for our interpretation of the country characteristics analyzed.

The above-mentioned analysis of Crucini et al. (2005) focused on the cross-sectional distribution of deviations from the LOP for a smaller and changing group of EU countries, but a very large number of specific product prices. They explain differences across countries in the average LOP deviation across goods in each country, and the variance of prices across countries for each good, using some of the same variables we use. They find that the mean deviation of product prices (relative to the average of the included countries) in each country is close to zero once income per capita is controlled for (Crucini et al. 2005, p. 726). The variance across countries for each good is largely explained by two characteristics of the industries to which the goods belong, namely, the trade/output ratios of the industries and the importance of "nontradable" inputs in each industry (Crucini et al. 2005, p. 729), estimated from the 1988 UK I-O table. They conclude that more of the variance is explained by the industries' nontraded input shares than by the trade/output ratios. Some of their broad conclusions, including the role of per capita income and of tradability, and the need to account for the characteristics of inputs are consistent with ours. Our analysis highlights the role of wage dispersion in explaining product price differences and how the effects of country characteristics, including per capita 
income, are modified by product characteristics such as tradability and labor intensity. In the remaining sections we develop the implications of our results.

\section{How Important Are These Price Determinants for Individual Product Prices?}

How important are the price level determinants we have measured? The country with the highest price level (aside from Japan, the price level for which we could not explain without a dummy variable) was Norway, and the country with the lowest price level was Portugal. The average price of a product in Norway was more than 60 per cent higher than in Portugal. The difference in per capita income between Norway and Portugal alone, if all other factors were at the average levels for the 20 countries, could have accounted for a difference in price levels of those two countries of 21 per cent, according to the equation of Table 1.

In contrast to per capita income, wage compression is a variable directly, or indirectly, affected by policy. The country with the widest wage dispersion, on average, was Canada, with the United States following closely. The country with the narrowest dispersion, or the greatest wage compression, was Sweden, with Norway and Belgium following closely. The difference in wage dispersion between Canada and Sweden, all other variables held at the 20-country average, was enough to make prices in Sweden a third higher than in Canada, according to the same equation of Table 1.

The actual price level for the average product was almost 40 percent higher in Sweden than in Canada. The effect of slightly higher Canadian per capita income in raising Canadian prices was more than offset by the much larger effect of Sweden's lower wage dispersion in raising Swedish prices. 
These are substantial effects on aggregate price levels. However, according to our price equation, the effects on individual prices are modified by the characteristics of the products, such as their tradability and labor intensity. For example, the effect of the higher per capita income of the United States, the highest income country, relative to Portugal would be greatly reduced for the most tradable products, (Table 2). These would be about the same price in the United States and in Portugal, while the least tradable product, would be 40 percent more expensive in the United States. High tradability greatly dampens the effect of income on prices.

Labor intensity also affects the impact of income differences on prices. Given the difference in per capita income between the United States and Portugal, but setting other values at the average levels, the most labor-intensive product would be more than 60 percent more expensive in the United States than in Portugal. The prices of the least labor intensive products would be only about 20 percent higher in the United States.

The effects of wage dispersion, too, were modified by product characteristics, as can be seen by comparing countries with the extremes of wage dispersion, Canada and Sweden (Table 3). The high wage dispersion in Canada reduced prices in Canada by 10 percent for the most tradable products but by 27 percent for the least tradable relative to prices in Sweden. Similarly, it reduced Canadian prices relative to Swedish prices by almost 40 percent for the most laborintensive products but by only 21 percent for the least labor intensive ones.

\section{TABLES 2 AND 3 ABOUT HERE .}

Clearly, institutions that promote wage compression have considerable effects on consumer prices. As noted by Björklund and Freeman (1997) in a comparison between Sweden and the United States, if wage policy means that the less skilled are paid more than they would have been in a more market driven system, someone has to bear the cost. Our calculations 
support their conjecture that in the case of less-traded goods and services, that someone is, at least partly, the consumer.

\section{Product Prices and Product Consumption}

One consequence of higher prices for some products, whether they stem from high overall wage levels or high prices for unskilled labor, or high distribution costs, could be a lower level of consumption of those products, given the other characteristics of a country. Table 4 shows the logarithmic relation between the relative price of product $i$ in country $j$, in comparison to its price in other countries, and the consumption share of product $i$ in GDP in country $j$, relative to the share in other countries (pooled for all years).

The negative effect of a higher relative price on relative consumption is statistically significant in the pooled data for all years, even without any other determining variables. The price elasticity indicated by the pooled data is 0.68 . When we add country $j$ real income per capita as a determinant of relative consumption share, the price elasticity for the pooled data rises to 0.76 .

\section{TABLE 4 ABOUT HERE}

Since we expect that these variables would have their strongest effect on products that are the least tradable and are labor-intensive and, particularly, intensive in their use of low-skill labor, we calculate the same equations for a few product groups with these characteristics. We exclude "Local bus, bus, train, tube, tram, and taxi services" because they are likely to be publicly owned or subsidized, and "Repair and Maintenance of Housing" because of differences among countries in the treatment of owner-occupied housing. The equations are shown, for five such product groups, all in service industries, in Table 5. 


\section{TABLE 5 ABOUT HERE}

In all the products, the relative price coefficient is negative and significant at the 1 percent level, as seen in Panel A of Table 5. Per capita income is usually significant, but the coefficients range from large positive to large negative. The relative price coefficients are in some cases larger and in some cases smaller than the coefficient for all products in Table 4. However, the degree of explanation is much greater for these unskilled-labor-intensive products, about 15-35 percent, as compared with 6 percent across all products. If we exclude per capita income from the equations, the degree of explanation hardly changes, except in the case of "Laundry and dry cleaning services", for which the income elasticity is high. The price coefficients are hardly affected by the omission of the income variable.

These equations imply large differences in the shares of GDP in unskilled-labor-intensive activities between the countries where they are high in price and those where they are relatively cheap, other characteristics equal. The implied differences in GDP shares are shown in Panel B of Table 5. For example in a country with Denmark's price for Laundry and dry cleaning, the share of that industry in GDP would amount to 38 percent of the typical country's share. It would be 92 percent, almost 3 times as much, in a country with Canada's relative price. The share of Restaurants and take-aways in GDP in a country with Sweden's relative prices for these services would be 55 percent of the typical country's share. It would be 172 percent of the average country's share, three times as much, in a country with New Zealand's relative price for these services.

Panel C of Table 5 shows the actual shares of GDP, instead of the theoretical ones of Panel B. The price differences, given the actual levels of each country's characteristics, were associated with large differences in the consumption of unskilled-labor-intensive services. 
Denmark really did consume much less of its GDP in the form of "Laundry and dry cleaning services" than Canada did. And Sweden consumed much less of its GDP in the form of Restaurants and take-aways than New Zealand did. The differences in consumption presumably produced similarly large differences in employment in these industries, since these are activities of low tradability.

The effects of relative prices on actual consumption may be somewhat exaggerated, since do-it-yourself and grey market activity are especially close substitutes to services purchased in the market in the case of these low-skill, labor-intensive services. Often, the effect of high wage costs is compounded by high indirect taxes, making grey market production especially profitable for both firms and workers. Official statistics in Sweden, for example, recognize this and make substantial adjustments in the published data for underreporting of income in these services, up to 35 percent for "Hairdressing" and 16 percent for "Restaurants" in 1996 (See Davis and Henrekson, 2010, pp. 237-238). The United States makes similar adjustments to the national accounts, although it is hard to match them to the industry classification used here. As far back as 1977, they were approximately 5 percent in retail trade and services (Parker, 1984, p. 24). The exaggeration of the price effect depends on the extent to which the various countries adjust their accounts for underreporting.

The connection between labor market policy and employment shares is not a simple one, however. Freeman and Schettkat (2001), comparing Germany and the United States, find that the much higher wage dispersion in the United States partly reflects a higher dispersion of skills in the United States than in Germany. They suggest that wage differences may not tell the whole story and that, among other things, one also needs to take account of Germany's higher nonwage labor costs (paid vacation time, payroll taxes) and tax-benefit wedges, which would impact 
especially on labor intensive services. These costs, higher in Germany than in the United States, mean that the dispersion of labor costs in Germany, and the difference from the United States, is understated by the wage comparison. (See also Davis and Henrekson 2004.)

Overall, our results tally with the findings of other studies of the effect of labor market policies on relative employment patterns. By tracing the effect of relative prices on consumption shares, we provide support, via a different route, for the idea (Freeman and Schettkat 2001; Fredriksson and Topel 2010; Davis and Henrekson 2010) that the smallness of the share of the low-skill, labor-intensive private service sector in many European countries relative to that in the United States is at least to some extent due to their higher price of low-skilled labor.

\section{Conclusions}

Per capita real income, wage compression, and exchange rate fluctuations, in combination with the tradability and labor intensity in production and distribution of individual products, explain a substantial part of international differences in individual product prices of goods and services. In general, higher per capita income raises prices, and that influence is stronger on more labor-intensive products, but weaker on more tradable products. A higher degree of wage compression at the lower end of the wage distribution (lower wage dispersion) in a country tends to raise prices, particularly for more labor-intensive products. The role we hypothesized for wage compression, or wage dispersion, is reinforced by its relation to the labor intensity of products.

The role of product tradability is confirmed by its effect on the impact of higher per capita income: more tradable products being less affected by a country's income level. And it is 
confirmed also by its effect on the wage dispersion coefficient: The effect of wage compression in raising product prices is weakened by high tradability of the product or service.

The role of short- or medium-term exchange rate fluctuations is also confirmed in our data. Medium-term deviations of nominal exchange rates from longer-run trends or fluctuations are not offset by price changes in the short run, but represent changes in real exchange rates.

All our variables combined can explain almost half of the observed aggregate price difference between a high-price country such as Norway and a low-price country such as Portugal. The difference in wage dispersion alone between a high-dispersion country such as the United States and a low-dispersion country such as Sweden was enough to raise aggregate prices in Sweden by 30 percent. The higher wage dispersion in the United States was enough to offset the effect of higher US per capita income on US prices.

Our estimates suggest that wage dispersion is key in understanding why a high income country such as the United States has a much larger private low-skill service sector than many European countries. This conclusion is reinforced by our finding that a high relative price of a product in a country is associated with a lower relative consumption of that product. The relationship between relative price and consumption share in a country is particularly strong for unskilled-labor-intensive products not primarily provided by governments. Since these are mostly services of low tradability, their high prices inhibit not only the consumption of these services, but also their production and their employment of low-skill workers. 


\section{Acknowledgments}

We are indebted to the Jan Wallander and Tom Hedelius Research Foundation for financial support. We are indebted to the OECD, and particularly to Annette Koechlin for the detailed country price data. A succession of skilled research assistants, including Xu Li, Hengyong Mo, and Jing Sun, has helped us with the statistical analyses as the paper and our ideas have evolved. 


\section{$\underline{\text { References }}$}

Bertola, G., Blau, F.D., Kahn, L.M. (2001). Comparative analysis of labor market outcomes: lessons for the US from international long-run evidence. National Bureau of Economic Research Working Paper \#8526, Cambridge, MA.

Bhagwati, J.N. (1984). Why are services cheaper in poor countries? Economic Journal, 94(373), March, 279-286.

Björklund, A., Freeman, R.B. (1997). Generating equality and eliminating poverty, the Swedish way. In R.B. Freeman, R. Topel, B. Swedenborg (Eds.), The welfare state in transition: reforming the Swedish model (National Bureau of Economic Research Conference Report) (pp. 33-78). Chicago and London: University of Chicago Press.

Blanchard, O., Giavazzi, F. (2003). Macroeconomic effects of regulation and deregulation in goods and labor markets. Quarterly Journal of Economics, 118(3), 879-907.

Conway, P., Janod, V., Nicoletti, G. (2005). Product market regulation in OECD countries: 1998 to 2003. Economics Department Working Paper No. 419, OECD, Paris

Crucini, M.J., Telmer, C.I., Zachariadis, M. (2005). Understanding European real exchange rates. American Economic Review, 95(3), 724-738.

Davis, S.J., Henrekson, M. (2004). Tax effects on work activity, industry mix, and shadow economy size: evidence from rich country comparisons. National Bureau of Economic Research Working Paper \#10509, Cambridge, MA.

Davis, S.J., Henrekson, M. (2005). Wage setting institutions as industrial policy. Labour Economics, 12(3), 345-377.

Davis, S.J., Henrekson, M. (2010). Economic performance and market work activity in Sweden after the crisis of the early 1990s. In R.B. Freeman, B. Swedenborg, R. Topel (Eds.), 
Reforming the welfare state: recovery and beyond in Sweden (National Bureau of Economic Research Conference Report). Chicago and London: University of Chicago Press.

Fredriksson, P., Topel, R. (2010). Wage determination and employment in Sweden since the early 1990s: wage formation in a new setting. In R.B. Freeman, B. Swedenborg, R. Topel (Eds.), Reforming the welfare state: recovery and beyond in Sweden (National Bureau of Economic Research Conference Report). Chicago and London: University of Chicago Press.

Freeman, R.B., Topel, R., Swedenborg, B., Editors (1997). The welfare state in transition: reforming the Swedish model (National Bureau of Economic Research Conference Report). Chicago and London: University of Chicago Press.

Freeman, R.B., Schettkat, R. (2001). Skill compression, wage differentials, and employment: Germany vs. the US. Oxford Economic Papers, 53(3), 582-603.

International Monetary Fund (2002). International financial statistics yearbook. Washington, DC: International Monetary Fund.

Koeniger, W., Leonardi, M., Nunziata, L. (2004). Labour market institutions and wage inequality. IZA Discussion Paper No. 1291, Bonn, September.

Kravis, I.B., Lipsey, R.E. (1983). Toward an explanation of price levels. Princeton Studies in International Finance, No. 52, Princeton University, International Finance Section, Department of Economics.

Kravis, I.B., Lipsey, R.E. (1988). National price levels and the prices of tradables and nontradables. American Economic Review, 78(2), 474-478. 
Lipsey, R.E., Swedenborg, B. (1996). The high cost of eating: causes of international differences in consumer food prices. Review of Income and Wealth, 42(2), 181-194.

Lipsey, R.E., Swedenborg, B. (1999). Wage dispersion and country price levels. In A. Heston, R.E. Lipsey (Eds.), International and interarea comparisons of income, output, and prices, studies in income and wealth, vol. 61 (pp. 453-477). Chicago: University of Chicago Press.

OECD (Organisation for Economic Cooperation and Development) (1991). Tables of producer subsidy equivalents and consumer subsidy equivalents, 1979-1990. Paris: OECD.

OECD (Organisation for Economic Cooperation and Development) (1996). OECD employment outlook, 1996. Paris: OECD.

OECD (Organisation for Economic Cooperation and Development) (1999). Purchasing power parities and real expenditures, 1996 Results. Paris: OECD

OECD (Organisation for Economic Cooperation and Development) (1999). National accounts, main aggregates, 1960-1997. Paris: OECD.

OECD (Organisation for Economic Cooperation and Development) (2003). National accounts of OECD countries, vol. I, 1990-2001. Paris: OECD.

OECD (Organisation for Economic Cooperation and Development) (2006). Eurostat-OECD PPP Programme 1996.

Parker, R.P. (1984). Improved adjustments for misreporting of tax return information used to estimate the National Income and Product Accounts, 1977. Survey of Current Business, 64, 17-25.

Ricardo, D. (1817). The principles of political economy and taxation. London: Dent (1911 ed.). 
Sanyal, K. K., Jones, R.W. (1982). The theory of trade in middle products. American Economic Review, 72(1), 16-31.

UNIDO (United Nations Industrial Development Organization) (2000). Industrial demandsupply balance database. UNIDO.

U.S. Department of Commerce (1991). Input-output accounts of the United States economy, diskette, 1982. Washington, DC: Bureau of Economic Analysis.

U.S. Department of Commerce (1994). Input-output accounts of the United States economy, diskette, 1987. Washington, DC: Bureau of Economic Analysis.

U.S. Department of Commerce (1997). Input-output accounts of the United States economy, diskette, 1992. Washington, DC: Bureau of Economic Analysis.

U.S. Department of Commerce (2002). Input-output accounts of the United States economy, diskette, 1997. Washington, DC: Bureau of Economic Analysis. 
Table 1

Regression Relating Price Levels to Country Characteristics \& Their Interactions with Product Characteristics 1985,1990,1993,1996, and 1999, Pooled

\begin{tabular}{cc}
\hline \hline & \\
GDPC (GDP per capita) & $0.3210^{* * *}$ \\
GDPC × LI (Labor intensity) & $(0.0311)$ \\
GDPC × TDB (Tradability) & $\left(0.1282^{* * *}\right.$ \\
WD (Wage dispersion) & $-0.1182^{* * *}$ \\
& $(0.0098)$ \\
WD $\times$ TDB & $-0.5112^{* * *}$ \\
WD $\times$ LI & $(0.0305)$ \\
& $0.1167 * * *$ \\
XRR (Deviation from 9-year averages) & $(0.0095)$ \\
& $-0.1291^{* * *}$ \\
Country Dummies & $(0.0223)$ \\
Japan & $1.0476^{* * *}$ \\
Constant & $(0.0545)$ \\
No. of Observations & $0.3993 * * *$ \\
Adj. R-squared & $(0.0198)$ \\
\hline
\end{tabular}

Robust Standard errors in parentheses;

$* * *$ significant at $1 \%$

Note:

Year dummies are included in the regressions. Agricultural protection is included as a variable in the equations for some food products, but the coefficients are not shown here. 
Table 2

Price Differences Between Highest and Lowest Per Capita

Income Countries Implied

by Equation in Table $1^{\mathrm{a}}$

\begin{tabular}{|c|c|c|}
\hline \multicolumn{3}{|c|}{ A. For Most and Least Tradable Products } \\
\hline \multirow{2}{*}{ Income Per Capita } & \multicolumn{2}{|c|}{ Tradability } \\
\hline & Lowest $^{\mathrm{b}}$ & Highest $^{\mathrm{c}}$ \\
\hline Highest (U.S.) & 1.157 & 0.970 \\
\hline Lowest (Portugal) & 0.824 & 0.974 \\
\hline Highest Income as \% of Lowest & 140.4 & 99.5 \\
\hline \multicolumn{3}{|c|}{ B. For Most and Least Labor Intensive Products } \\
\hline \multirow{2}{*}{ Income Per Capita } & \multicolumn{2}{|c|}{ Labor Intensity } \\
\hline & Lowest $^{\mathrm{d}}$ & Highest $^{\mathrm{e}}$ \\
\hline Highest (U.S.) & 1.065 & 1.208 \\
\hline Lowest (Portugal) & 0.890 & 0.745 \\
\hline Highest Income as \% of Lowest & 119.7 & 162.1 \\
\hline \multicolumn{3}{|l|}{ Note: } \\
\hline \multicolumn{3}{|c|}{$\begin{array}{l}\text { a. The variables not listed are set at OECD averages; } \\
\text { b. Average of Hairdressers, Beauty Parlors, etc, and Eggs \& Egg Products; } \\
\text { c. Jewelry, Watches and Their Repair. } \\
\text { d. Average of Electricity, Education Fees, Town and Natural Gas; } \\
\text { e. Restaurants and Take-aways; }\end{array}$} \\
\hline
\end{tabular}


Table 3

Price Differences Between Countries with Highest and

Lowest Wage Dispersion Implied

by Equation in Table $1^{\mathrm{a}}$

A. For Most and Least Tradable Products

Wage Dispersion

Highest (Canada)

Lowest (Sweden)

Highest WD as \% of Lowest

\begin{tabular}{cc}
\multicolumn{2}{c}{ Tradability } \\
\hline Lowest $^{\mathrm{b}}$ & Highest $^{\mathrm{c}}$ \\
0.801 & 0.905 \\
1.098 & 1.003 \\
72.9 & 90.2 \\
\hline
\end{tabular}

B. For Most and Least Labor Intensive Products

Wage Dispersion

Highest (Canada)

Lowest (Sweden)

Highest WD as \% of Lowest

\begin{tabular}{cc}
\multicolumn{2}{c}{ Labor Intensity } \\
\hline Lowest $^{\mathrm{d}}$ & Highest $^{\mathrm{e}}$ \\
0.831 & 0.697 \\
1.045 & 1.105 \\
79.5 & 63.1 \\
\hline
\end{tabular}

Note:

a. The variables not listed are set at OECD averages;

b. Average of Hairdressers, Beauty Parlors, etc, and Eggs \& Egg Products;

c. Jewelry, Watches and Their Repair.

d. Average of Electricity, Education Fees, Town and Natural Gas;

e. Restaurants and Take-aways; 
Table 4

Relative Product Share ${ }^{a}$ in GDP as Function of Relative Product Price ${ }^{\mathrm{b}}$ and Real Per Capita Income:

Logarithmic Equations, c 1985,1990,1993,1996, and 1999, Pooled

\begin{tabular}{llc}
\hline \hline Relative Price & $-0.6771 * * *$ & $-0.7644 * * *$ \\
& $(0.0216)$ & $(0.0222)$ \\
Real GDP Per Capita & & $0.5986^{* * *}$ \\
& & $(0.0391)$ \\
Constant & $-0.3883^{* * * *}$ & $-0.3836 * * *$ \\
& $(0.0070)$ & $(0.0069)$ \\
No. of Observations & 19161 & 19161 \\
Adj. R-squared & 0.0488 & 0.0603 \\
\hline
\end{tabular}

$* * *$ significant at $1 \%$

Note:

a. Relative product share is the share of product $i$ in the real GDP of country $j$ relative to the average share in all 20 countries.

b. Relative product price is the price of product $\mathrm{i}$ in country $\mathrm{j}$ relative to the average price in all 20 countries.

c. Relative product shares of less than 0.0005 have been truncated. As a result, 130 relative country shares are omitted. 
Table 5

Relative Product Shares in GDP as Function of Relative Product Price and Real Per Capita Income, Logarithmic Equations, Five Unskilled-Labor-Intensive Products, 1985,1990,1993,1996, and 1999, Pooled

\begin{tabular}{|c|c|c|c|c|c|}
\hline \multicolumn{6}{|c|}{$\begin{array}{c}\text { Panel A: Relative Product Shares in GDP as Function of Relative Product Price } \\
\text { and Real Per Capita Income, Logarithmic Equations } \\
\text { Product } \\
\end{array}$} \\
\hline & 1 & 2 & 3 & 4 & 5 \\
\hline \multirow[t]{2}{*}{ Relative Price } & $-1.2375 * * *$ & $-1.1882 * * *$ & $-0.5451 * * *$ & $-0.9314 * * *$ & $-0.7371 * * *$ \\
\hline & $(0.3978)$ & $(0.1579)$ & $(0.1075)$ & $(0.2389)$ & $(0.2349)$ \\
\hline \multirow[t]{2}{*}{ Real GDP Per Capita } & $2.3466 * * *$ & $0.5259 *$ & $0.4200 *$ & $-1.3549 * *$ & -0.6047 \\
\hline & $(0.7078)$ & $(0.2797)$ & $(0.2207)$ & $(0.5512)$ & $(0.5778)$ \\
\hline \multirow[t]{2}{*}{ Constant } & $-0.5895 * * *$ & $-0.2132 * * *$ & $-0.0981 * * *$ & $-0.6094 * * *$ & $-0.4138 * * *$ \\
\hline & $(0.1291)$ & $(0.0509)$ & $(0.0329)$ & $(0.0940)$ & $(0.0922)$ \\
\hline No. of Observations & 95 & 99 & 99 & 99 & 96 \\
\hline Adj. R-squared & 0.1450 & 0.3588 & 0.2076 & 0.2505 & 0.1494 \\
\hline
\end{tabular}

Panel B: Predicted Relative Product Shares in GDP by Equation in Panel A:

For Countries with Highest and Lowest Relative Price Levels, Holding Real Per Capita Income and Wage Dispersion at Averages, Logarithmic Equations

\begin{tabular}{lrrrrr} 
& \multicolumn{5}{c}{ Product } \\
\cline { 2 - 6 } Highest & 1 & 2 & 3 & 4 & 5 \\
\cline { 2 - 6 } Lowest & 0.3773 & 0.5524 & 0.7175 & 0.3454 & 0.4683 \\
\hline Differences & 0.9176 & 1.7242 & 1.4816 & 1.3924 & 1.6628 \\
Ratios & -0.5403 & -1.1718 & -0.7641 & -1.0470 & -1.1945 \\
\hline
\end{tabular}

Panel C: Actual Relative Product Shares in GDP For Countries with Highest and Lowest Relative Price Levels

\begin{tabular}{lrrrrr} 
& \multicolumn{5}{c}{ Product } \\
\cline { 2 - 6 } Highest & 1 & 2 & 3 & 4 & 5 \\
\cline { 2 - 5 } Lowest & 0.9798 & 0.4182 & 0.7992 & 0.1668 & 0.4079 \\
\hline Differences & 1.8066 & 1.4571 & 1.3030 & 1.0204 & 2.1918 \\
Ratios & -0.8268 & -1.0389 & -0.5039 & -0.8537 & -1.7838 \\
\hline
\end{tabular}

Note: $* *$ significant at $5 \%, * * *$ significant at $1 \%$

Product 1: Laundry and dry cleaning; in panel B and panel C, highest relative price: Denmark; lowest relative price: Canada;

2: Restaurants and Take-aways; in panel B and panel C, highest relative price: Sweden; lowest relative price: New Zealand;

3: Hairdressers, beauty parlors, etc; in panel B and panel C, highest relative price: Norway; lowest relative price: Portugal.

4: Pubs, cafés, bars and tea-rooms; in panel B and panel C, highest relative price: Norway; lowest relative price: Portugal.

5: Domestic services; in panel $\mathrm{B}$ and panel $\mathrm{C}$, highest relative price: Norway; lowest relative price: Portugal. 
Appendix 1: Tables and Figures

Table 6: Median Levels of Tradability in Various Product Groups

\begin{tabular}{clr}
\hline $\begin{array}{c}\text { Basic Headings } \\
\text { for Eurostat- } \\
\text { OECD PPP } \\
\text { Programme }\end{array}$ & \multicolumn{1}{c}{ Commodity Group } & Median \\
\hline 111 & Food, beverages and tobacco & 20.83 \\
112 & Clothing and footwear & 61.95 \\
113 & Gross Rent, fuel and power & 0.49 \\
114 & Household equipment and operation & 20.75 \\
115 & Medical and health care & 0.02 \\
116 & Transport and communication & 7.78 \\
117 & Education, recreation and culture & 10.00 \\
118 & Miscellaneous goods and services & 1.22 \\
131 & Collective consumption by government & 0.00 \\
132 & Education & 0.00 \\
133 & Medical Supplies and Services & 0.01 \\
134 & Social security and welfare services / & 0.01 \\
141 & Recreation, cultural, religious affairs & 54.56 \\
142 & Machinery and equipment & 0.00 \\
\hline
\end{tabular}

Source: UNIDO (2000) \& US Department of Commerce, 2002. 
Table 7: Average Combined Transportation, Wholesale, and Retail Trade Margins

\begin{tabular}{clc}
\hline $\begin{array}{c}\text { Basic Headings } \\
\text { for Eurostat- } \\
\text { OECD PPP }\end{array}$ & \multicolumn{1}{c}{ Commodity Group } & Average Margin \\
Programme & \multicolumn{1}{c}{ Food, beverages and tobacco } & 34.20 \\
111 & Clothing and footwear & 78.74 \\
112 & Household equipment and & 39.11 \\
& operation & 50.43 \\
114 & Medical and health care & 24.48 \\
115 & Transport and communication & 41.79 \\
117 & Education, recreation and culture & 56.83 \\
118 & Miscellaneous goods and services & 16.57 \\
141 & Machinery and equipment & \\
\hline
\end{tabular}

Source: US Department of Commerce, 1991, 1994, 1997, and 2002. 
Figure 1

Price Level Related to Income Per Capita, Pooled

1.6

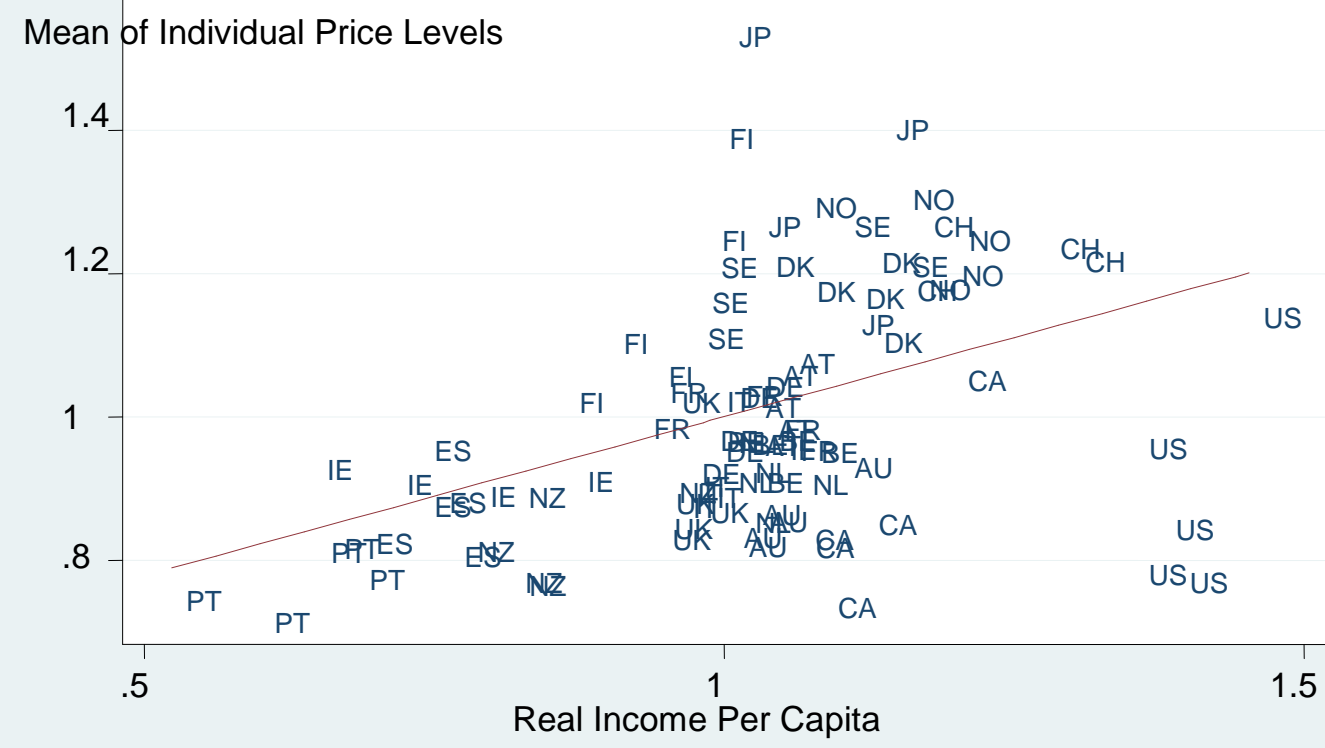

Figure 2

\section{Price Level Related to Wage Dispersion, Pooled}

1.6

Mean of Individual Price Levels JP

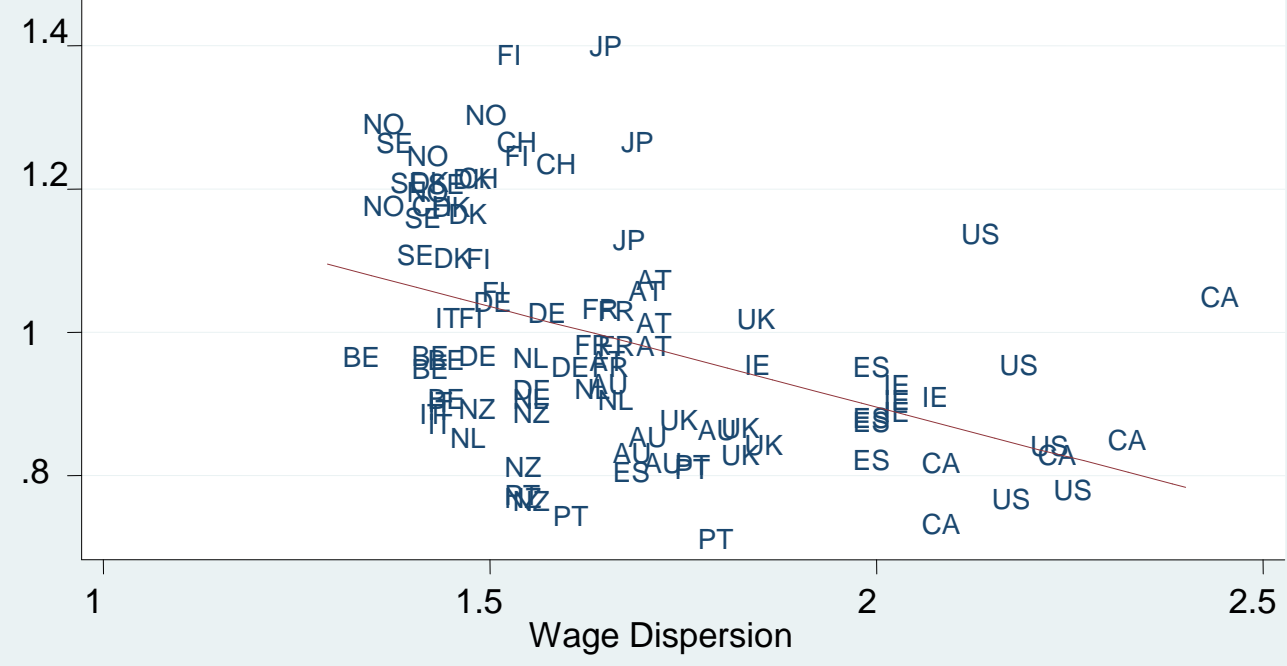


Appendix 2: Data

The countries included in this study are Australia, Austria, Belgium, Canada, Denmark, Finland, France, Germany, Ireland, Italy, Japan, the Netherlands, New Zealand, Norway, Portugal, Spain, Sweden, Switzerland, the United Kingdom and the United States. The products, along with some that were dropped because we could not match them with product characteristics, are listed in OECD (2006).

Both product prices and real domestic products per capita are derived by OECD from data collected, mainly by Eurostat, as part of the International Comparison Program (ICP), coordinated by the World Bank. What we refer to as "products" are what are called "basic headings" in the ICP. As is explained by the OECD, "In principle, a basic heading consists of a small group of similar well-defined products." The paper goes on to say that "In practice, a basic heading is defined by the lowest level of final expenditure for which explicit expenditure weights can be estimated. Thus, an actual basic heading can cover a broader range of goods or services than is theoretically desirable." (OECD, 1999, p. 15).

Product price in this paper is the price of an individual product (or basic heading) in each country, measured in national currency and converted into U.S. dollars by the average exchange rate against the U.S. dollar during that year, as reported in OECD (2001). The individual product prices are for 182 categories of goods and services out of the 218 reported by the OECD. Some of the products had to be dropped from our calculations because the categories could not be marched to other variables in our equations. After conversion to US dollars, each product price was taken as a relative to the average price in all the OECD countries. 
Real gross domestic product per capita is gross domestic product in current year international prices, as reported in OECD (2003). The figure for each country in each year was taken as a per cent of the average for all OECD countries.

Wage dispersion, our measure of wage compression, is measured by the ratio of the median wage to the wage at the lowest decile. Each country's wage dispersion in each year was taken as a per cent of the average for all OECD countries. The wage dispersion data for years before 1996 are from OECD (1996). Data for later years, and some revisions of earlier data, were obtained directly from the OECD "Database on Earnings." For maximum consistency across countries, wage dispersion was calculated from the distribution of men's earnings where it was available, but for Denmark and Norway, the distributions are for the earnings of men and women. The wage distribution of the year of the price observation was used where it was available, but in some cases, that of the closest year had to be taken. Most of the country wage dispersion levels varied only slowly over time.

Tradability is measured by the extent of international trade (exports plus imports) in a product (including services), relative to the value of production. The figure for each product or service was taken as a per cent of the average for all the products and services, so that the variable used in the equations is relative tradability. For goods, the ratios are based on UNIDO (2000), which provides export, import, and production data for ISIC Revision 2 industries. Tradability for goods is assumed to be a fixed characteristic of a product and data for a single year are used for the calculation, 1991 for 41 countries, 1992 data for three, 1990 for one, and 1986 for one. The data were inadequate for calculating measures for all our individual years.

We could not find corresponding data for services for many countries. The most detailed breakdown was for the United States, for which we used the 1997 Input-Output table of the 
Bureau of Economic Analysis, which provided exports, imports, and domestic production for a large number of services, and the U.S. tradability measures for services were used for all the countries.

The tradability measures are assumed to be constant, not in absolute terms, but in the ranking of products. An indicator of the stability of a measure of tradability for all goods and services based on U.S. Input-Output data spanning most our period, is the rank correlation between the measured tradability in 1982 and that in 1997 . The correlation is .93 , suggesting a quite stable ranking.

The exchange rate deviation for each year is calculated from nominal exchange rates relative to the dollar, in terms of dollars per unit of other currency, from International Monetary Fund (2002). Each country's rates from 1970 to 2002 were averaged across years, and the series were put in terms of relatives, with the period average $=100$. These relatives were averaged across all 19 or 20 countries, and were recalculated with the average of all countries in each year as the base (=100). A nine-year moving average was fitted to each country's series of relatives, and deviations from this nine-year index form our exchange rate deviation measure. Coefficients of equations with exchange rate deviations based on three-year moving averages were very similar to those in the equations used here except for the coefficients of the exchange rate deviation itself and some year dummies.

Market support estimates are measures of agricultural protection. Market Support = Consumer Subsidy Equivalent / (Total Consumption - Transfer to Consumers from Taxpayers) * 100 , where the consumer subsidy equivalent is calculated by the OECD from data on price differences for agricultural products between individual country and international markets. Data are from OECD (1991) and later from the OECD website). 
Labor intensity is measured as the ratio of the number of employees to the value added in an industry. The relative labor intensities across products, based on U.S. Input-Output tables, are relatively stable over the span of years used, with the rank correlation between 1985 and 1999 at 0.77 and the Pearson $r$ at 0.91 .

Since the prices are at the final product level, we wish to include the labor intensity of the margin between the producer price and the final price, which we take to be the sum of costs incurred in three broad industry groups, transportation, wholesale trade, and retail trade to deliver the final product. Unfortunately, there is no subdivision of these costs according to the product involved, so that labor intensities in these three industry groups are assumed to be identical across all products that are transported, all that are wholesaled, and all that are retailed. Thus, the labor intensity for a product $(i)$ is measured as:

$$
L I=\frac{E M P_{i}+E M P_{T R} * \frac{T C_{i}}{\sum T C}+E M P_{W T} * \frac{W T_{i}}{\sum W T}+E M P_{R T} * \frac{R T_{i}}{\sum R T}}{(V A-T)_{i}+(V A-T)_{T R} * \frac{T C_{i}}{\sum T C}+(V A-T)_{W T} * \frac{W T_{i}}{\sum W T}+(V A-T)_{R T} * \frac{R T_{i}}{\sum R T}}
$$

where

$E M P_{i}$ : Employment in industry $i$;

$E M P_{T R}$ : Total employment in Transportation industries;

$E M P_{W T}$ : Total employment in Wholesale Trade industry;

$E M P_{R T}$ : Total employment in Retail Trade industry;

$(V A-T)_{i}$ : Value added excluding indirect taxes in industry $i$;

$(V A-T)_{T R}$ : Value added excluding indirect taxes in Transportation industries;

$(V A-T)_{W T}$ : Value added excluding indirect taxes in Wholesale Trade industry;

$(V A-T)_{R T}$ : Value added excluding indirect taxes in Retail Trade industry;

$T C_{i}$ : Transportation costs in industry $i$;

$W T_{i}$ : Wholesale margin in industry $i$;

$R T_{i}$ : Retail margin in industry $i$;

$\sum T C$ : Total transportation costs in all industries;

$\sum W T$ : Total wholesale margin in all industries;

$\sum R T$ : Total retail margin in all industries. 
The labor intensity data for each product in each year was taken as a per cent of the average for all products. Data come from U.S. Input-Output tables for 1982, 1987, 1992 and 1997. The calculations of labor intensity for 1996 and 1999 are both based on the 1997 U.S. Input-Output tables. Our use of U.S. data to represent the world labor intensity implies an assumption that these product characteristics do not vary greatly from country to country. 